$10 \mathrm{IKC}-234$

\title{
MANTLE LITHOSPHERE BENEATH WYOMING BASED ON SLOAN AND KELSEY LAKE - I KIMBERLITE XENOCRYSTS
}

\author{
Ashchepkov I.V. ${ }^{\text {a }}$, Downes H.b, Mitchell R. ${ }^{\mathrm{c}}$, Vladykin N.V. ${ }^{\mathrm{d}}$, Palessky S.V. ${ }^{\mathrm{a}}$ \\ anstitute of Geology and Mineralogy, SD RAS, Novosibirsk, Russia \\ ${ }^{\mathrm{b}}$ Birkbeck College, University of London, UK \\ ' Lakehead University, Ontario, Canada \\ ${ }^{\mathrm{d}}$ Institute of Geochemistry SD RAS, Irkutsk, Russia
}

\section{MINERALOGY OF XENOCRYSTS}

Megacrysts and xenocrysts and their intergrowths from two Paleozoic kimberlite pipes Sloan and Kelsey Lake-1 (KL-1) in northern Colorado were analyzed by EPMA and LAM ICPMS in Analytic Centre IGM SB RAS. We also investigated a smaller number of xenocrysts from the Chicken Park and Iron Mountain kimberlites.

GARNETS from Sloan (Fig. 1a) mainly fall in the lherzolite field (Coopersmith et al., 2003) with up to $12.5 \mathrm{Wt} \% \mathrm{Cr}_{2} \mathrm{O}_{3}$. Compared to the $\mathrm{KL}-1$ garnets which reach $14 \mathrm{Wt}_{\mathrm{Cr}_{2}} \mathrm{O}_{3}$ and show deviations to the harzburgite fields, this is less favorable for the diamond grade.

CR-DIOPSIDES from Sloan (Fig. 2) are less depleted but similar to those in the Daldyn field Siberia, (Fig. 2b), showing similar divisions into groups including sheared peridotites. Cpx from Sloan are divided into two groups corresponding to the lower and upper parts of the mantle sections. The KL-1 diopsides show a trend that is restricted in $\mathrm{FeO}$ with sharp growth of $\mathrm{Al}$, $\mathrm{Cr}$ and $\mathrm{Na}$ together with $\mathrm{Fe}$, typical for metasomatites and hybrid varieties from Alakit field, Yakutia (Ashchepkov et al., 2004).

CR-SPINELS from Sloan (Fig. 3a) form a straight peridotitic $\mathrm{Cr}-\mathrm{Al}$ trend. The $\mathrm{TiO}_{2}, \mathrm{~V}_{2} \mathrm{O}_{3}$ and $\mathrm{Cr}_{2} \mathrm{O}_{3}$ increase together while $\mathrm{NiO}, \mathrm{ZnO}$ and $\mathrm{Nb}_{2} \mathrm{O}_{3}$ decrease, indicating the greater influence of protokimberlite melt at the base of the SCLM
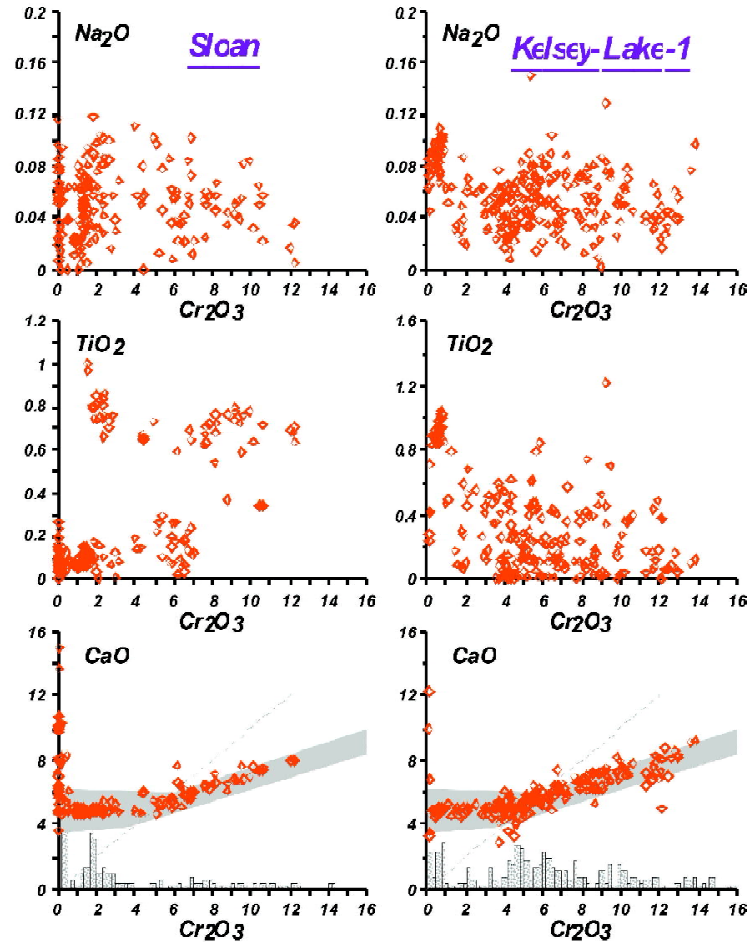

Fig.1. Variations of major element compositions from garnets from Sloan (a) and Kelsey Lake-1 (b). Pyrope compositions relate to lherzolitic field (Sobolev et al 1973) (up to $14 \mathrm{Wt} \% \mathrm{Cr}_{2} \mathrm{O}_{3}$ ).

and its differentiation to the top. Chromites from the KL-1 pipe coincide (Fig.4) with the Cr-rich part of the Sloan spinel trend showing dispersion of $\mathrm{TiO}_{2}$. 

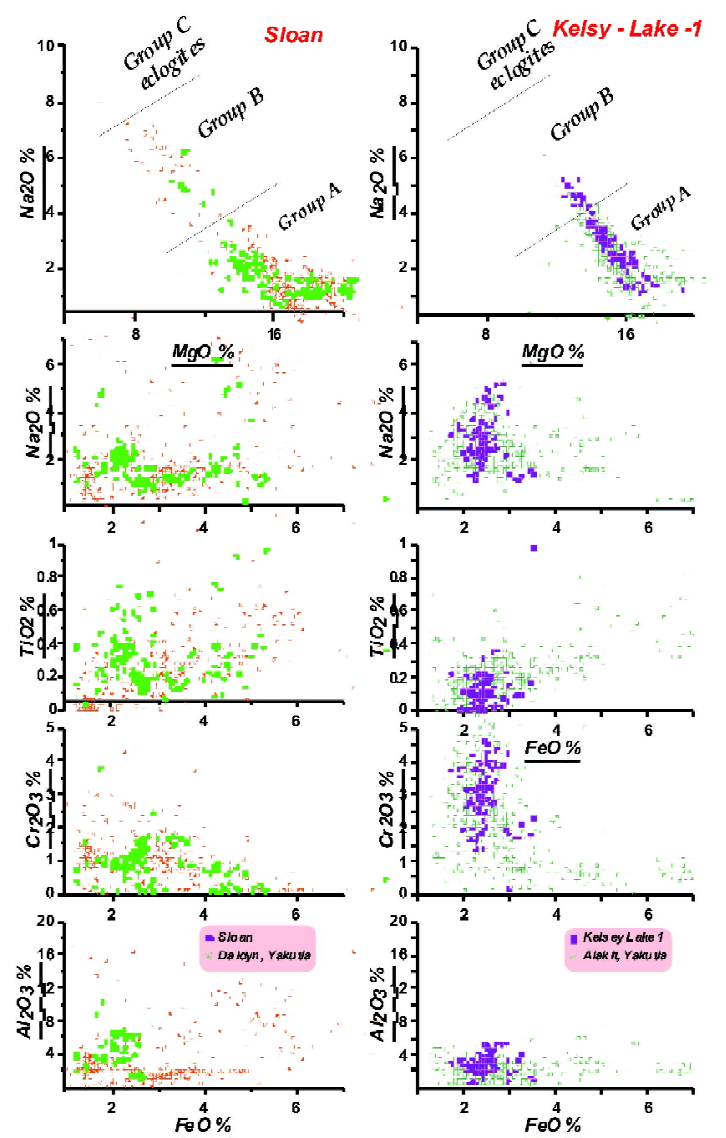

Fig.2. Variations of major element compositions of clinopyroxenes from Sloan (a) and Kelsey Lake 1 (b), in comparison with data for Daldyn and Alakit regions, Yakutia (Ashchepkov et al ., 2010)

ILMENITES from Sloan pipe (Fig. 4a) $\left(\mathrm{TiO}_{2}\right.$ from 56 to $\left.44 \mathrm{Wt} \%\right)$ show a $\mathrm{Cr}$-rich metasomatic branch with decreases in $\mathrm{Al}_{2} \mathrm{O}_{3}$ and $\mathrm{FeO}$, and flat $\mathrm{NiO} . \mathrm{Cr}_{2} \mathrm{O}_{3}$ shows a general increase to left part and $\mathrm{Cr}$-low branch with low $\mathrm{Cr}$ and Al. The KL-1 ilmenite extended trend (Fig. 4b) (36-60\% $\mathrm{TiO}_{2}$ ) is dispersed because many ilmenites occur in intergrowths with exsolved rutile. Nevertheless the general tendencies are similar as for Sloan ilmenites showing enrichment in $\mathrm{Cr}$ and essential enrichment in $\mathrm{MnO}$ to $8 \mathrm{Wt}$ $\%$. Ilmenites from Chicken Park are mildly $\mathrm{Mg}$ (8-10 $\mathrm{Wt} \% \mathrm{MgO})$ and $\mathrm{TiO}_{2}$-rich. They are slightly enriched in $\mathrm{Al}_{2} \mathrm{O}_{3}$ and show relatively low $\mathrm{Ni}$ content and highly varying $\mathrm{V}_{2} \mathrm{O}_{3}$.
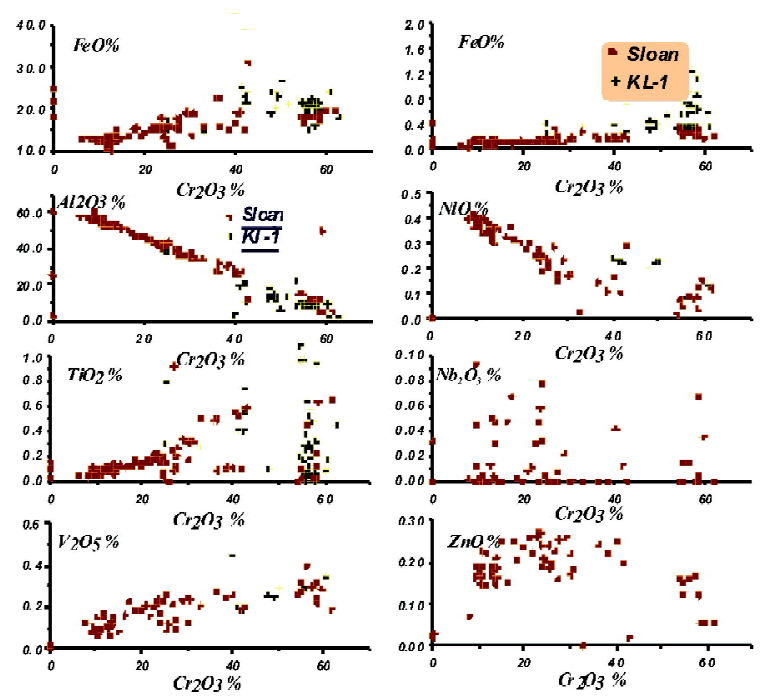

Fig.3 Variations of major element compositions for $\mathrm{Cr}$ - spinels from 1 Sloan and $2 \mathrm{KL}-1$ pipes
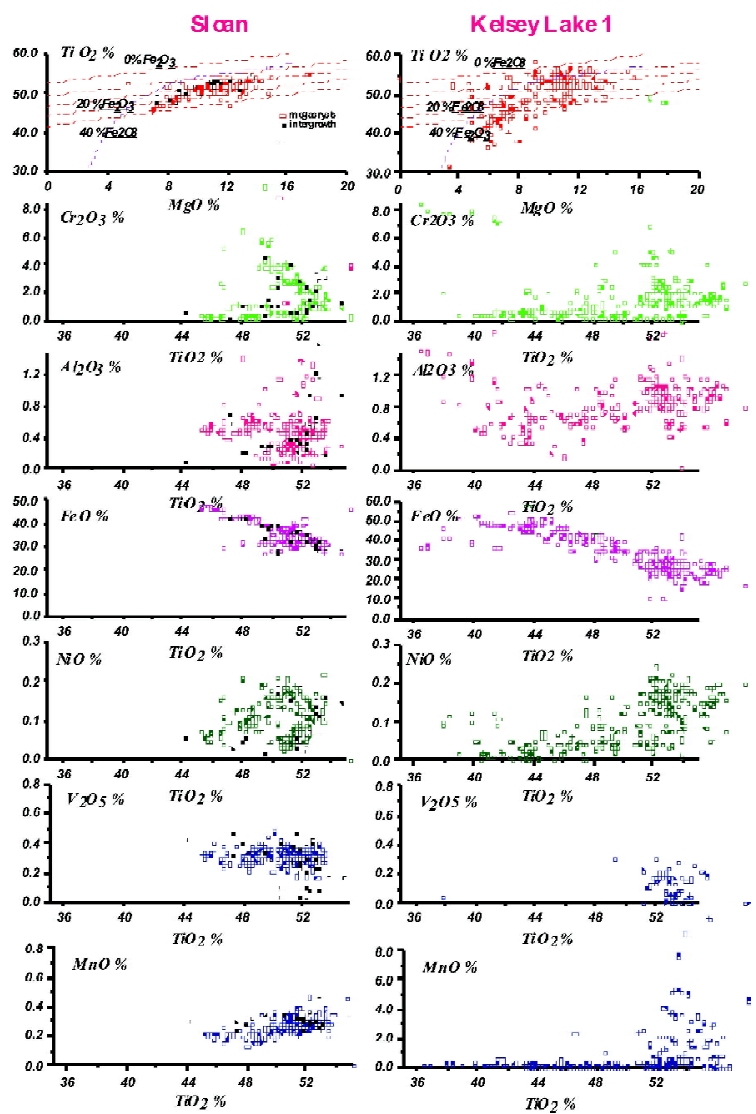

Fig.4 Variations of major element compositions of ilmenites from Sloan (a) (1-xenocrysts 2-intergrowths) and Kelsey Lake (b) 


\section{0 $^{\text {th }}$ International Kimberlite Conference, Bangalore - 2012}

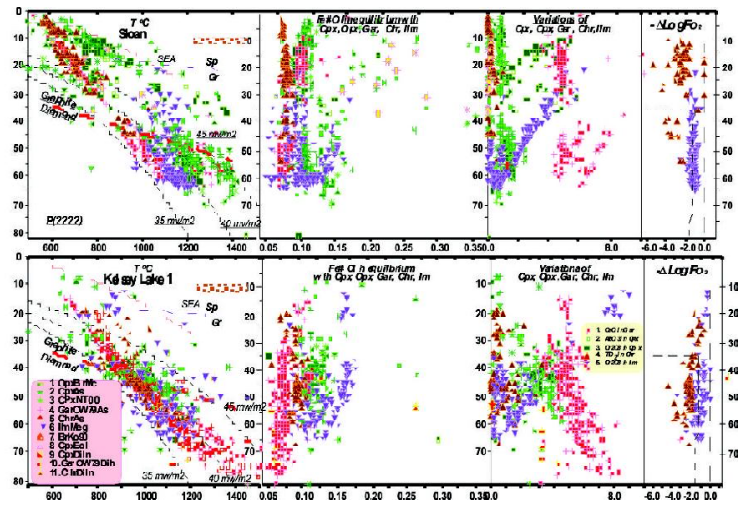

Fig.5. PTXFO, conditions for the new data and for all previous data set of deep seated inclusions from kimberlite pipes Symbols see (Ashchepkov et al ., 2010). Diamond inclusions (Schulze, 1992; Schulze et al., 2008). Symbols see Fig 5.

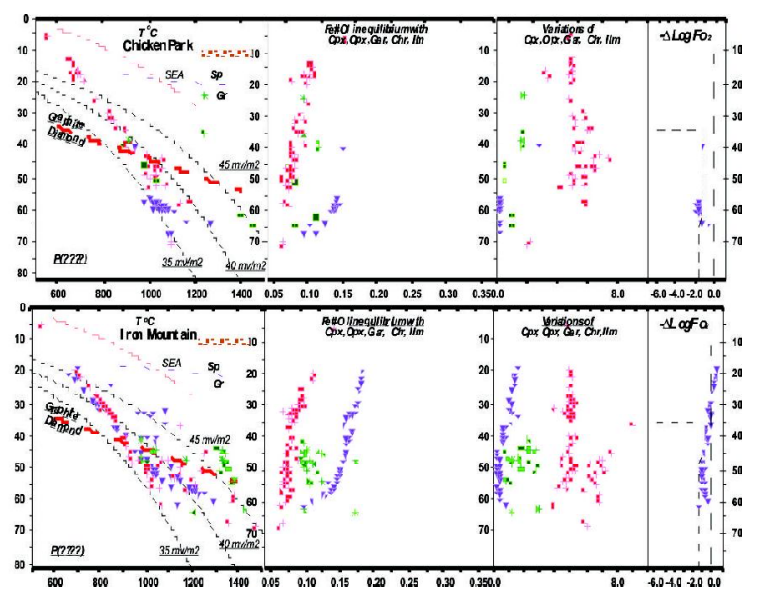

Fig.6. PTXFO, diagrams for the Vendian Chicken Park and Ordovician Iron Mountain pipes (Data from Griffin et al., 2004; Schulze et al ., 1995a; McCallum \& Eggler, 1976; 1979). Symbols see Fig 5.

\section{THERMOBAROMETRY AND RECONSTRUCTIONS OF MANTLE SECTIONS.}

The subcratonic lithospheric mantle (SCLM) structure beneath the Sloan and Kelsey Lake kimberlites has been reconstructed using xenocrysts $(\sim 2000$ analyses made in IGM, Novosibirsk) and monomineral methods described in Ashchepkov et al. (2010) which give close PT estimates to those obtained by the best methods
(Brey \& Kohler, 1990; Nimis \& Taylor, 2000; McGregor, 1974).

The SCLM beneath Sloan pipe is divided to lower and upper parts at 40-30 kbar by a layer traced by Opx, omphacites $\left(6 \mathrm{wt} \% \mathrm{Na}_{2} \mathrm{O}\right)$, low$\mathrm{Cr} \mathrm{CPx}$ and $\mathrm{Cr}$ ilmenites and diopsides from metasomatitic veins. In the lower part PT for lherzolitic garnets enriched in $\mathrm{TiO}_{2}$ trace $37 \mathrm{mw} /$ $\mathrm{m}^{2}$ geotherm to SCLM base (75-60 kbar) showing the inflection (Nixon, Boyd,1973). Two advective branches rising from the base are marked by $\mathrm{Cr}$ diopsides of sheared type. PT estimates for ilmenites and Ti- garnets reflect PT fractionation of protokimberlites $(\mathrm{Fe} \#=17)$. Metasomatic veins with ilmenites show a stepped $\mathrm{Cr}_{2} \mathrm{O}_{3}$ rise $(\mathrm{Fe} \#=$ 12) formed at lower temperatures but higher then fresh peridotitic (Fe\# 8-10). The deeper $\mathrm{Cr}$ spinels show $\mathrm{TiO}_{2}$ and $\mathrm{NiO}$ contents decreasing to the top of the SCLM, also influenced by melts. The upper level $<30$ kbar shows three PT paths: the hottest for Opx and $\mathrm{Fe}-\mathrm{Cpx}$, lower for garnets and $\mathrm{Cpx}$ and the lowest for Sp, Cpx and Gar with Fe\# 9- 11 correspondingly. The latter are Sp lherzolites.

The lower temperature mantle sequence beneath KL-1 relates to $<35 \mathrm{mw} / \mathrm{m}^{2}$ geotherm. HT branches for $\mathrm{Cr}$-rich garnets in of SCLM base show an increase in $\mathrm{Ca}$. Joined ilmenites and $\mathrm{Cr}$ diopside heated to $40 \mathrm{mw} / \mathrm{m}^{2}$ trends (Fe\# 15-17;

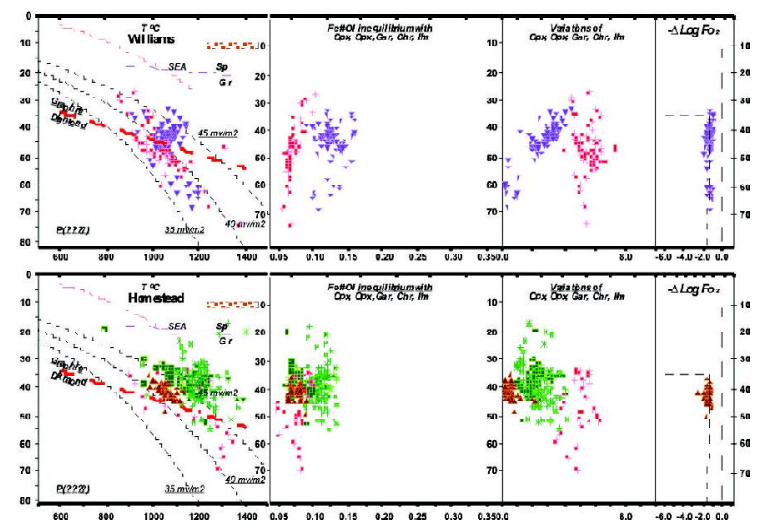

Fig.7. $\mathrm{PTXFO}_{2}$ diagrams for the minerals from concentrates Eocene Williams (Hearn, McGee, 1984) and Homestead (Hearn, 2004) kimberlite pipes (Montana) Symbols see Fig 5. 
11-14; 9-10) result from refertilization. PT conditions also tend to be divided to relatively low heated and those overheated at the shallow level. Chromite PT estimates show split trends (Fe\# 10; 12) at 55-40kbar.

The HT conditions with sub-adiabatic path are detected for some ilmenites in the middle and upper parts of the lithospheric mantle section.

Xenocrysts from Chicken Park Vendian kimberlites (Lester \& Larson, 1996; Coopersmiths et al , 2003; Hausel, 1998) allow to reconstruct SCLM divided at 40 kbar by a heated horizon where the garnet PT trend reveals an inflection with high rise in Fe\# to the top. The base of SCLM is heated to $1500^{\circ} \mathrm{C}$ (PT for Opx).

The SCLM beneath Iron Mountain is divided at $40 \mathrm{kbar}$. In the upper part Fe\# in garnets increases towards the top. In lower part increase in $\mathrm{CaO}$ and $\mathrm{Fe}$-rich $\mathrm{Cpx}$ refer to refertilizations as well as polybaric branch of AFC differentiated ilmenites, Cpx show Fe\#s intermediate between those for garnets and ilmenites.

\section{GEOCHEMISTRY}

Sloan peridotitic garnets show rounded REE patterns with humps to $\mathrm{Nd}$ to $\mathrm{Gd}$ and small $\mathrm{U}, \mathrm{Ba}$ $\mathrm{Nb}$, Ta peaks, varying $\mathrm{Zr}$ indicating mixed subduction and metasomatic features. The Cpx patterns increase the inclinations to low mantle part $50<\mathrm{Gd} / \mathrm{Yb}<80$. The small troughs of $\mathrm{Zr}$ are typical for all of them. Enrichment in Ba is a result of the presence of fluid inclusions. The trace elements for ilmenites are very uniform with the strong peaks in $\mathrm{Ta}-\mathrm{Nb}$, weaker ones in $\mathrm{Hf}-\mathrm{Zr}$ and evident for $\mathrm{Pb}$. But some ilmenites have higher $\mathrm{Rb}$ and $\mathrm{Ba}$, probably due to metasomatism. One ulvospinel shows inclined REE patterns and moderate enrichment in HFSE. Eclogitic Cpx show peaks in $\mathrm{Ba}$. $\mathrm{U}, \mathrm{Sr}, \mathrm{Pb}$.

Garnet form KL-I with increasing Cr reveals lower REE and progressive S-shaping, with pressure increase. Cpx REE show rotation about Gd due to modal garnet variations in their source. $\mathrm{Zr}-\mathrm{Hf}$ depletion is rare but $\mathrm{Ta}-\mathrm{Nb}$ are common, increasing with $\mathrm{U}$ peaks which is common for subduction processes.

Deep-seated Cpx LREE -Th enrichment reflects carbonatite signs, $\mathrm{Cpx}$ from $\mathrm{Sp}$ lherzolites displays LREE U, Ba rise relating to ancient subduction. Ilmenites reveal inclined REE patterns with varying HREE and showing lower $\mathrm{U}, \mathrm{Ta}-\mathrm{Nb}$ and $\mathrm{Zr}$-Hf peaks common for metasomatites.

\section{DISCUSSION}

The Sloan and KL-1 pipes reveal different processes of extensive reaction of the mantle
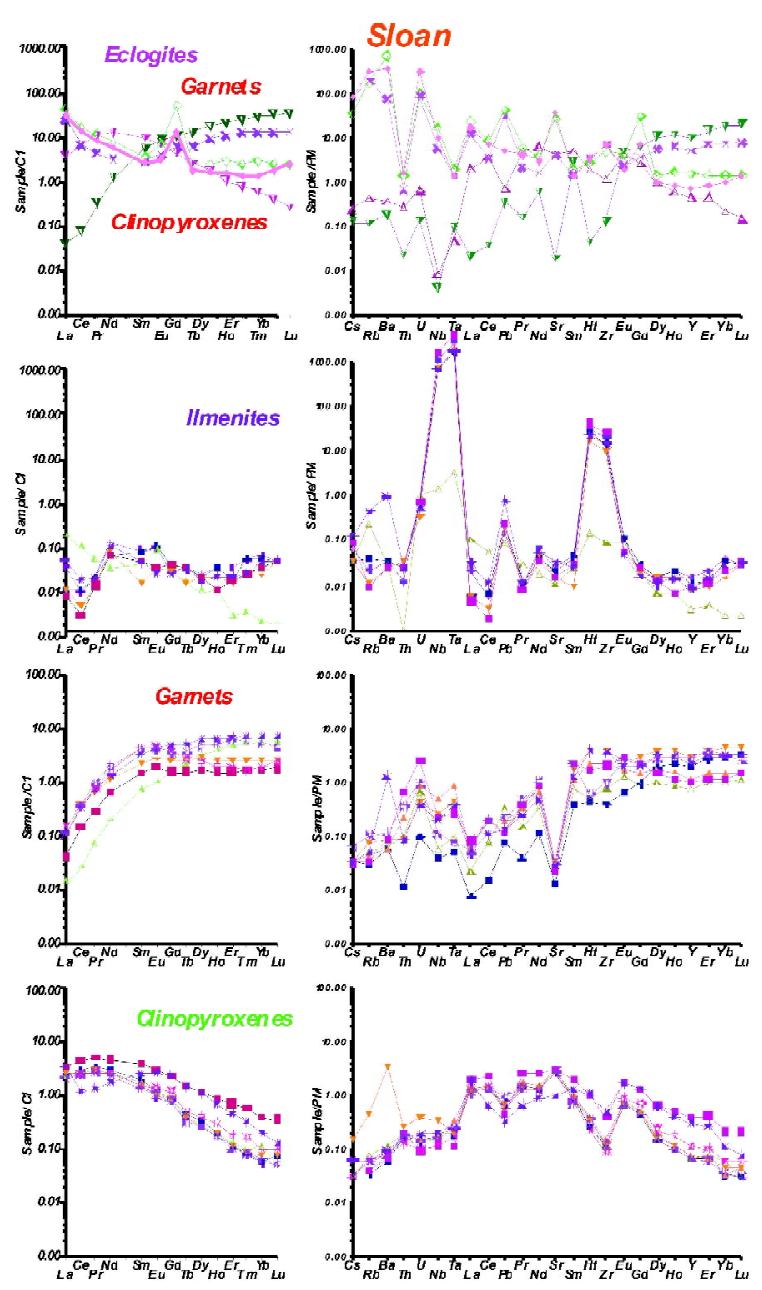

Fig. 8. Trace element patterns for minerals from deep-seated inclusions from Sloan pipe 


\section{0 $^{\text {th }}$ International Kimberlite Conference, Bangalore - 2012}

protolith with ancient melts and protokimberlites. The Sloan SCLM was subjected from base to top with protokimberlites reactions revealed by the uniform Cpx trace elements from all parts of the mantle section and continuous trends of chromites. The KL-1 SCLM is diverse in composition containing abundant subduction matter (high $\mathrm{Mn}$, $\mathrm{Ba}$ and $\mathrm{Sr}$ ) was metasomatized and homogenized by subduction-related melts, plumes and their alkaline derivatives (O'Brien et al., 1995) and then by protokimberlites. The high heterogeneity of the mantle beneath the Wyoming craton was probably an original feature of the Wyoming craton keel composed of high angle slabs merged in craton margins. Position and compositions of the eclogites in the mantle section of different pipes is uncertain. The Re/Os ages for the peridotitic minerals indicate Archean to Proterozoic events and later refertillizations (Carlson \& Irving, 1994; Rudnick et al., 1999).

Grant RBRF 05-11-00060à 11-05-91060-

\section{PICSà}

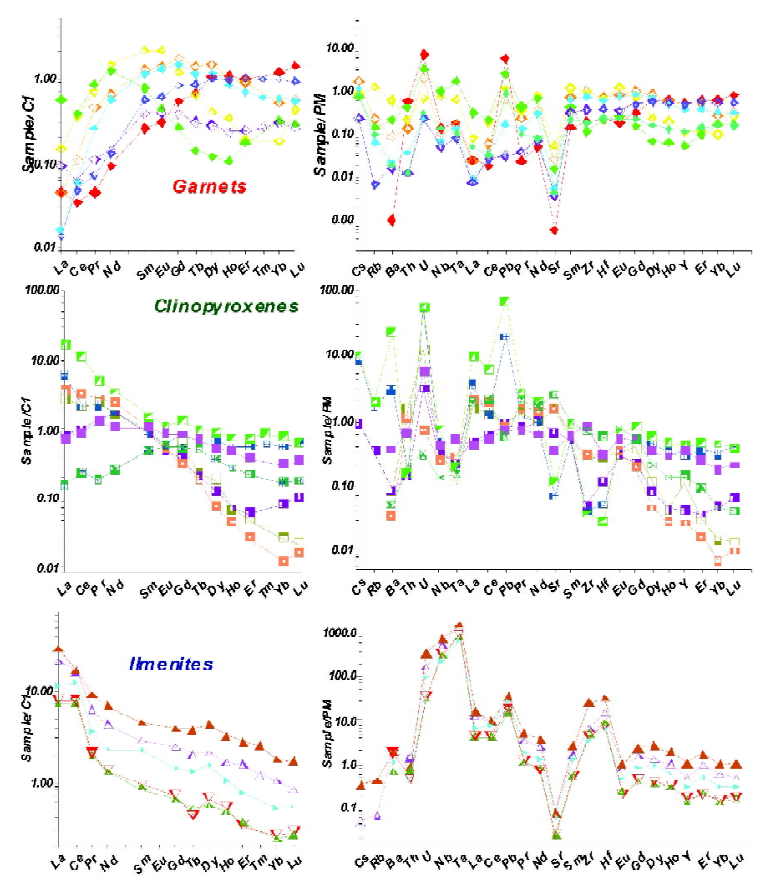

Fig. 9. Trace element patterns for minerals from deep-seated inclusions from Kelsey Lake-1 pipe.

\section{References}

Ashchepkov I.V., Vladykin N.V., Mitchell R.H., Howard C., Garanin V.G., Saprykin A.I., Khmelnikova O.S., Anoshin G.N. 2001. Mineralogy of the mantle xenocrysts from KL-1 (Kelsey lake) kimberlite pipe, Colorado. Revista Brasileira de Geociencias, 31, 645-652.

Ashchepkov, I.V., Vladykin, N.V., Nikolaeva, I.V., Palessky, S. V., Logvinova, A.M., Saprykin, A. I. \& Khmel'nikova, O. S., Anoshin, G.N., 2004. Mineralogy and Geochemistry of Mantle Inclusions and Mantle Column Structure of the Yubileinaya Kimberlite Pipe, Alakit Field, Yakutia. Doklady of Russian Academy of Sciences Earth Science Sections, 395 (4), 517-523.

Ashchepkov, I.V., Pokhilenko, N.P., Vladykin, N.V., Logvinova, A.M., Kostrovitsky, S.I., Afanasiev, V.P., Pokhilenko, L.N., , Kuligin, S.S., Malygina, L.V., Alymova, N.V., Khmelnikova, O.S., Palessky, S.V., Nikolaeva, I.V., Karpenko, M.A., Stagnitsky, Y.B. Structure and evolution of the lithospheric mantle beneath Siberian craton, thermobarometric study. 2010. Tectonophysics. 485, 17-41.

Brey, G.P., Kohler, T. 1990. Geothermobarometry in four-phase lherzolites. II. New thermo-barometers, and practical assessment of existing thermobarometers. Journal of Petrology, 31, 13531378.

Carlson R.W, Irving A.J. 1994. Depletion and enrichment history of subcontinental lithospheric mantle: an $\mathrm{Os}, \mathrm{Sr}, \mathrm{Nd}$, and $\mathrm{Pb}$ isotopic study of ultramafic xenoliths from the northwestern Wyoming craton. Earth Planet Sci Lett, 126, $457-$ 472

Carlson R.W., Irving A.J., Hearn B.C.,Jr. 1999. Chemical and isotopic systematics of peridotite xenoliths from the Williams kimberlite, Montana: clues to processes of lithospheric formation,modification and destruction. /In Proc.7th Int.Kimberlite Conf.(eds. J.J.Gurney, J.L.Gurney, M.D.Pascoe, and S.H.Richardson). Red Roof Design, Cape Town, v.1, 90-98.

Carlson R. W., Irving A.J., Schulze D.J., Carter B., Hearn J. Timing of Precambrian melt depletion and Phanerozoic refertilization events in the lithospheric mantle of the Wyoming Craton and 


\section{0 $^{\text {th }}$ International Kimberlite Conference, Bangalore - 2012}

adjacent Central Plains Orogen. 2004. Lithos. 77, 453- 472

Carlson R. W., James D. E. 2011. Craton Destruction :An Ongoing Example in Western North America. /International Conference On Craton Formation And Destruction Abstracts. Beijing. 14-15.

Coopersmith H. G., Mitchell R.H., Hausel W. D. 2003. Kimberlites And Lamproites Of Colorado And Wyoming, Usa. Guidebook for the VIIIth International Kimberlite Conference, Colorado and Wyoming Field Trip. 32 .

Eggler D.H., McCallum M.E., Smith C.B. 1979. Megacryst assemblages in kimberlite from northern Colorado and southern Wyoming: petrology, geothermometry-barometry and areal distribution. /In Kimberlites, Diatremes, and Diamonds: Their Geology, Petrology, and Geochemistry (eds. F.R.Boyd and H.O.A.Meyer). American Geophysical Union, Washington, DC, 213-226.

Griffin W.L., Suzanne O'ReillyY., Doyle B.J., Pearson N.J., Coopersmith H., Kivi K., Malkovets V., Pokhilenko N.. 2004. Lithosphere mapping beneath the North American plate Lithos, 77, 873922.

Hausel W.D. 1998. Diamonds and mantle source rocks in the Wyoming Craton, with a discussion of other US occurrences/ Wyoming State Geological Survey Report of Investigations 53, 93 p.

Heaman L.M., Kjarsgaard B.A., Creaser R. A. 2004. The temporal evolution of North American kimberlites. Lithos. 76, 377-397.

Hearn B. C. 2004. The Homestead kimberlite, central Montana, USA: mineralogy, xenocrysts, and uppermantle xenoliths. Lithos, 473-491.

Hearn B. C. Jr., McGee, E. S. 1984. Garnet peridotites from Williams kimberlites, north-central Montana, USA/in

Kornprobst, J., ed., Kimberlites II: The Mantle and Crust-Mantle Relationships: Amsterdam, Elsevier, p. 57-70.

Lester A., Larson E. 1996. New geochronological evidence for the Late Proterozoic emplacement of Colorado Wyoming kimberlites belt. EOS Trans. Am. Geoph. Union, 77(41), 821.

McCallum M.E., Eggler, D.H. Diamonds in an upper mantle peridotite nodule from kimberlite in southern Wyoming. Science. 1976. V. 192. P. 253256.
MacGregor I.D. 1974 The system MgO-A12O3-SiO2: solubility of A12O3 in enstatite for spinel and garnet peridotite compositions. Am Mineral. 59, 110-119

Nimis, P. Taylor, W.. Single clinopyroxene thermobarometry for garnet peridotites. Part I. Calibration and testing of a $\mathrm{Cr}$-in-Cpx barometer and an enstatite-in-Cpx thermometer. //Contrib. Mineral. Petrol. , 2000. v.139 (5), pp.541-554.

Nixon P.H., Boyd F.R. 1973. Petrogenesis of the granular and sheared ultrabasic nodule suite in kimberlites. In: Nixon PH (ed) Lesotho kimberlites. Lesotho Nat Dev Corp Maseru, Lesotho, 1973, 48-56.

O’Brien H. E., Irving A. J., McCallum I. S., Thirwall M. F. 1995. Sr, $\mathrm{Nd}$ and $\mathrm{Pb}$ isotopic evidence for the interaction of post-subduction asthenospheric potassic mafic magmas of the Highwood Montana, Montana, USA, with ancient Wyoming craton lithospheric mantle. Geochimica et Cosmochima Acta. 59, 4539-4556.

O’Neill, H. St. C. \& Wall, V. J. 1987. The olivine orthopyroxene-spinel oxygen geobarometer, the nickel precipitation curve, and the oxygen fugacity of the Earth's upper mantle. Journal of Petrology, 28, 1169-1191

Rudnick R.L., Ireland T.R., Gehrels G., Irving A.J., Chesley J.T., Hanchar J.M. 1999. Dating mantle metasomatism: U-Pb geochronology of zircons in cratonic mantle xenoliths from Montana and Tanzania. In Proc.7th Int. Kimberlite Conf.(eds. J.J.Gurney,J.L.Gurney, M.D.Pascoe, and S.H.Richardson). Red Roof Design, Cape Town, vol. 2, 728-735.

Schulze, D. J. 1992. Diamond Eclogite from Sloan Ranch, Colorado and its Bearing on the Diamond Grade of the Sloan Kimberlite. Economic Geology, 87,. 2175-2179.

Schulze, D. J., Anderson, P. F. N., Hearn, B. C., Jr., and Hetman, C. M. 1995. Origin and Significance of Ilmenite Megacrysts and Macrocrysts from Kimberlite. International Geology Review, 37, 780-812.

Schulze, D. J., Coopersmith H. G., Harte B.,, Pizzolato L.-A. 2008, Mineral inclusions in diamonds from the Kelsey Lake Mine, Colorado, USA: Depleted Archean mantle beneath the Proterozoic Yavapai province. Geochimica et Cosmochimica Acta, 72, 1685-1695. 
Sobolev N.V., Lavrent'ev Yu.G., Pokhilenko N.P., Usova L.V. 1973. Chrome-rich garnets from the kimberlites of Yakuti and their parageneses. Contrib Mineral Petrol., 1973, v.40; pp. 39-52. 